\title{
Development of parasitic Maculinea teleius (Lepidoptera, Lycaenidae) larvae in laboratory nests of four Myrmica ant host species
}

\author{
M. Witek · P. Skórka $\cdot$ E. B. Śliwińska $\cdot$ P. Nowicki $\cdot$ \\ D. Moroń · J. Settele · M. Woyciechowski
}

Received: 5 February 2010/Revised: 21 October 2010/Accepted: 25 February 2011 / Published online: 12 March 2011

(C) The Author(s) 2011. This article is published with open access at Springerlink.com

\begin{abstract}
Maculinea butterflies are social parasites of Myrmica ants. Methods to study the strength of host ant specificity in the Maculinea-Myrmica association include research on chemical and acoustic mimicry as well as experiments on ant adoption and rearing behaviour of Maculinea larvae. Here we present results of laboratory experiments on adoption, survival, development and integration of M. teleius larvae within the nests of different
\end{abstract}

\footnotetext{
M. Witek (凹)

Department of Animal and Human Biology, University of Turin,

Via Accademia Albertina 13, 10123 Turin, Italy

e-mail: mawitus@yahoo.co.uk

M. Witek · E. B. Śliwińska · P. Nowicki · M. Woyciechowski Institute of Environmental Sciences, Jagiellonian University, Gronostajowa 7, 30-387 Kraków, Poland

E. B. Śliwińska

e-mail: ewa-sliwinska@wp.pl

P. Nowicki

e-mail: piotr.nowicki@uj.edu.pl

M. Woyciechowski

e-mail: michal.woyciechowski@uj.edu.pl

P. Skórka

Institute of Zoology, Poznań University of Life Sciences,

Wojska Polskiego 71c, 60-625 Poznań, Poland

e-mail: skorasp@pocza.onet.pl

\section{Moroń}

Institute of Systematics and Evolution of Animals, Polish Academy of Science, Slawkowska 17, 31-016 Kraków, Poland e-mail: dawidmoron@poczta.onet.pl

\section{J. Settele}

Department of Community Ecology,

UFZ-Helmholtz Centre for Environmental Research,

Theodor-Lieser-Str. 4, 06120 Halle, Germany

e-mail: josef.settele@ufz.de
}

Myrmica host species, with the objective of quantifying the degree of specialization of this Maculinea species. In the laboratory, a total of 94 nests of four Myrmica species: M. scabrinodis, M. rubra, M. ruginodis and M. rugulosa were used. Nests of $M$. rubra and M. rugulosa adopted M. teleius larvae more readily and quickly than $M$. ruginodis colonies. No significant differences were found in the survival rates of $M$. teleius larvae reared by different ant species. Early larval growth of M. teleius larvae differed slightly among nests of four Myrmica host species. Larvae reared by colonies of M. rugulosa which were the heaviest at the beginning of larval development had the lowest mean larval body mass after 18 weeks compared to those reared by other Myrmica species. None of the M. teleius larvae was carried by $M$. scabrinodis or M. rubra workers after ant nests were destroyed, which suggests a lack of integration with host colonies. Results indicate that Myrmica species coming from the same site differ in their ability to adopt and rear M. teleius larvae but there was no obvious adaptation of this butterfly species to one of the host ant species. This may explain why, under natural conditions, all four ants can be used as hosts of this butterfly species. Slight advantages of particular Myrmica species as hosts at certain points in butterfly larval development can be explained by the ant species biology and colony structure rather than by specialization of M. teleius.

Keywords Myrmecophily - Larval development . Lycaenidae $\cdot$ Social parasitism $\cdot$ Host-parasite relationship

\section{Introduction}

Colonies of social insects, such as ants, bees or termites are used by numerous similar-sized organisms as hosts, provi- 
ding shelter and food resources (Hölldobler and Wilson, 1990; Thomas et al., 2005). Social parasitism requires adaptations to infiltrate and integrate into host colonies (Hölldobler and Wilson, 1990) where more efficient exploitation of host resources is generally connected with increasing host specificity (Thomas and Elmes, 1998; Elmes et al., 1999). Thomas et al. (2005) proposed two hypotheses to explain variation in the strength of host specificity in social parasites. The first hypothesis states that host specificity depends on the level of penetration of a social parasite towards the most protected and resource-rich niches within a social colony. The second hypothesis suggests that host specificity can also depend on the developmental stage of the social parasite when entering the social colony; the earlier the stage the higher the host specificity.

One of the best known interactions in which the level of host specificity has been investigated is between the butterfly genus Maculinea van Eecke, 1915 and their Myrmica (Latreille, 1804) host ants (Thomas and Settele, 2004; Thomas et al., 2005). Maculinea larvae first feed on specific food plants and in their final instar they are adopted by Myrmica workers and taken into ant colonies where they spend 11-23 months (Thomas et al., 1998; Schönrogge et al., 2000; Witek et al., 2006). It is known that Maculinea larvae are picked up and carried to nests by workers of any Myrmica species that encounter them (Elmes et al., 1991a, 2002; Akino et al., 1999; Thomas, 2002). The next and more important step is 'initial integration' into the ant society which takes place within the first $24-48 \mathrm{~h}$ inside the colony. During this time some larvae are accepted but others are killed or neglected (Wardlaw et al., 2000; Elmes et al., 2004; Schönrogge et al., 2004). The final step termed 'full integration' determines survival and development of $\mathrm{Macu}$ linea larvae, including overwintering, inside host colonies (Elmes et al., 2004; Schönrogge et al., 2004). Both 'initial' and 'full' integration are much more successful in colonies of the main host although sometime colonies of other Myrmica species can rear a small fraction of a butterfly population (Thomas et al., 1989).

A higher integration with Myrmica colonies is observed in M. alcon ([Denis and Schiffermüller], 1775) and $M$. 'rebeli'(Hirschke, 1904), which both follow a cuckoo strategy, where they are treated as ant brood and are fed directly by ant workers with even higher priority than the ant larvae (Elmes et al., 1991b; Thomas et al., 1998). Integration is lower in predatory species such as $M$. arion (Linnaeus, 1758) and M. teleius (Bergsträsser, 1779), which prey upon ant larvae (Thomas and Wardlaw, 1990, 1992). Numerous studies have been carried out on host ant specificity between Maculinea butterflies and their Myrmica host ants in recent years. Most of them are based on recorded frequency distribution of Maculinea pupae in relation to the host ant species they were found with (Elmes et al., 1994,
1998; Stankiewicz and Sielezniew, 2002; Als et al., 2004; Tartally and Csősz, 2004; Woyciechowski et al., 2006; Tartally and Varga, 2008; Witek et al., 2008, Patricelli et al., 2010). A more mechanistic understanding of host specificity in Maculinea-Myrmica association has been achieved by studying chemical and acoustic mimicry (Schönrogge et al., 2004; Nash et al., 2008; Barbero et al., 2009) and through the investigation of ant adoption and rearing behaviour (Als et al., 2001; Elmes et al., 2004; Sielezniew and Stankiewicz, 2007, Nash et al., 2011). The latter studies were restricted to the cuckoo feeding $M$. 'rebeli' and $M$. alcon and they showed that caterpillars were more readily adopted by the main host species and that after adoption they achieved a high social rank within the ant society, while with other Myrmica species they appeared to survive only because they were merely tolerated (Thomas et al., 1989; Als et al., 2001; Elmes et al., 2004; Schönrogge et al., 2004; Sielezniew and Stankiewicz, 2007).

However, there is surprisingly little information about adoption and rearing behaviour of predatory Maculinea species such as M. teleius (Fiedler, 1990; Figurny, 1999). The first detailed studies on the host specificity of $M$. teleius showed that M. scabrinodis (Nylander, 1864) was its main host species (Thomas et al., 1989) while recent studies that recorded the frequency distribution of $M$. teleius pupae across the host ant species have shown that its larvae can successfully develop and survive inside nests of other Myrmica species from the same site (Stankiewicz and Sielezniew, 2002; Tartally and Varga, 2008; Witek et al., 2008).

To gain a better basic understanding of the interactions between this Maculinea species and its Myrmica hosts we studied the adoption, survival, growth and integration of M. teleius larvae inside ant colonies in laboratory experiments. The life cycle of M. teleius was completed within nests of four Myrmica species previously recorded as the hosts in our study site in the Kraków region (Witek et al., 2010), where it was found that M. ruginodis (Nylander, 1864) nests can provide slightly better conditions than colonies of M. scabrinodis. Nevertheless, it was difficult to detect whether M. teleius has a main host in the investigated area. We expected that a comparison of the timing of adoption of M. teleius larvae, survival rate and integration within colony hierarchy among different Myrmica species would be a good measurement of host ant specificity of M. teleius in our study area.

\section{Materials and methods}

Collection of Myrmica ants and Maculinea larvae

Myrmica colonies of four species [M. scabrinodis, M. rubra (Linnaeus, 1758), M. ruginodis and M. rugulosa (Nylander, 
1849)] and M. teleius caterpillars were collected in August 2004 at three meadows belonging to one metapopulation system of $M$. teleius (Nowicki et al., 2007) located in the Vistula river valley in southern Poland $\left(50^{\circ} 01^{\prime} \mathrm{N} ; 19^{\circ} 54^{\prime} \mathrm{E}\right)$, four $\mathrm{km}$ south-west of Kraków centre. The total number of collected colonies was 94 (meadow 1: 12 colonies of M. scabrinodis and 12 of M. rubra; meadow 2: 12 colonies of M. scabrinodis, $12 M$. rubra and 12 M. rugulosa; and meadow 3: 12 nests of $M$. scabrinodis, 10 M. rubra and $12 M$. ruginodis). For each collected nest we established single Myrmica sub-colony consisting of one queen, 250 workers and $300 \mathrm{mg}$ of ant brood (ant larvae and pupae). Artificial nests for each sub-colony were constructed from a transparent plastic box $(28 \times 17 \times 6 \mathrm{~cm})$ with walls coated with fluon to prevent ants from escaping. Part of the box floor was covered with fine plaster, which was moistened with water to maintain a suitable humidity. The plaster was covered by a flowerpot saucer with an entrance notch which was treated by ants as the suitable nest (ant brood was kept there). A small box with food was situated at the opposite end of the artificial colony space. Once per week Myrmica ants were fed with glucose and frozen fly larvae.

Caterpillars of M. teleius were obtained from the flowers of its food plant Sanguisorba officinalis L. (Dicotyledonopsida: Rosaceae). From each meadow, 500 single stems of $S$. officinalis were collected and in the laboratory all plants from one meadow were gathered into bunches of 25 stems with the base of the stems placed in water. Each bunch was enclosed in a plastic bag to prevent caterpillars from escaping. Bunches were shaken every morning and evening to obtain the larvae. Only the fourth-instar larvae (determined according to Śliwińska et al., 2006) collected in the morning were used for the experiment (so as to use only fresh fourth-instar larvae). Each caterpillar was immediately weighed to $1 \mathrm{mg}$ precision using a Cole-Parmer (Acculab, USA) balance.

\section{Adoption of M. teleius larvae}

Caterpillars obtained from S. officinalis were introduced into ant colonies collected from the same meadow. The larvae were put in small boxes which were placed within the ants' living space at the furthest distance from the ant nest entrance. Only a single larva was introduced into each laboratory nest. The adoption time was measured as the time (min) from the first contact between the M. teleius caterpillar and a Myrmica worker until the larva was brought into the ant nest; continuous observation was conducted during the first $8 \mathrm{~h}$ (= $480 \mathrm{~min})$. When adoption did not occur within this time, the next observation was carried out after $20 \mathrm{~h}(=1,200 \mathrm{~min})$. If the larva was adopted between 8 and $20 \mathrm{~h}$, the exact time of adoption was unknown and in such cases we used the mean time of $14 \mathrm{~h}$ (=840 $\mathrm{min})$. When the caterpillar was not adopted within $20 \mathrm{~h}$ it was immediately replaced by a fresh one placed directly into the ant nest. Results from these colonies were not used for the analysis of the "adoption" experiment but combined with data from other colonies were used for the analysis of the survival and development of $M$. teleius larvae.

\section{Survival and development of $M$. teleius larvae}

Each Myrmica colony (94 artificial nests) contained one M. teleius larva. Survival and growth (body mass changes) of M. teleius larvae were assessed at 7-day intervals throughout the first 8 weeks after adoption. During this time the temperature in the ant colonies was maintained at $20^{\circ} \mathrm{C}$. In mid-October all ant nests were placed into climate controlled cabinets with a 10-h light and 14-h darkness cycle. The temperature in the cabinets approximated 18, 12, 10, 7, $5^{\circ} \mathrm{C}$ in October, November, December, January and the beginning of February, respectively. Then, in February, the temperature was raised to $8^{\circ} \mathrm{C}$, in March to $10^{\circ} \mathrm{C}$ and in April to $15^{\circ} \mathrm{C}$. This temperature cycle (with low winter temperatures) was similar to those described by Wardlaw et al. (1998). From mid-October to mid-April all measurements of larval growth and survival were made once per month. At the end of April all artificial nests with remaining larvae were moved to the lab with a temperature of $20^{\circ} \mathrm{C}$ and in a natural diurnal cycle, and subsequent survival and body mass changes were assessed at 14-day intervals. Observations continued until the beginning of July 2005. During each assessment every Myrmica colony was provided with the same amount of sugar and number of fly larvae. The initial amount of ant brood (as food for M. teleius larvae) was the same in each colony (300 mg). This amount was not artificially supplemented later in the experiment in order to keep the system as natural as possible (however, additional eggs were laid by Myrmica queen and workers, so that some brood was usually present as food for the butterfly caterpillars). Eleven Myrmica colonies lost their queens during the experiment, particularly in its early phase.

\section{Integration experiment}

Eight nests of M. rubra, nine nests of $M$. scabrinodis and $S$. officinalis stems (as a source of M. teleius caterpillars) were collected in August 2005 in the Kraków region. Each of the nests provided 150 workers, 1 queen and 13 ant larvae. Ants were kept in the laboratory for one week prior to the start of experiment. The collection and introduction of $M$. teleius larvae as well as the construction of artificial nests were conducted as described above for the adoption experiment.

Larvae of M. teleius obtained from S. officinalis were immediately placed into ant nests, one larva per nest. The experiment was carried out $48 \mathrm{~h}$ after the caterpillars were placed into Myrmica colonies. Ant nests were destroyed by 
moving the humid plasters and flowerpot saucers to the opposite side of the box (i.e. about $20 \mathrm{~cm}$ away). Observation started from this moment and finished 20 min after the last Myrmica larva was moved by workers into the new ant nest. It was recorded whether the Maculinea larvae were also taken to the new nests.

\section{Statistical analysis}

Most statistical analyses were conducted with Statistica 6.0 software (StatSoft, 2003), with the exception of the Log-rank test for which the SAS statistical software package was used (SAS Institute, 2004). Differences in the proportion of successful adoptions of $M$. teleius larvae among different Myrmica species were tested using Fisher's exact tests, generalized to more than two compared categories (Carr, 1980, as implemented at http://www.quantitativeskills.com/sisa/). There were no differences among the three meadows in the proportion of adoptions made by either $M$. scabrinodis or $M$. rubra colonies. Thus, data from all M. scabrinodis and $M$. rubra nests were pooled separately. The time of adoption of M. teleius larvae by, and their survival inside nests of, particular Myrmica species were analysed by Log-rank tests. To assess the median adoption time, censored data were also included as without them this value would be underestimated. To compare differences in body mass changes of M. teleius larvae reared by Myrmica hosts, repeated measures ANOVA was performed. To estimate the general growth pattern of $M$. teleius larvae inside ant colonies and to compare this with other Maculinea species, the body mass data of M. teleius larvae from nests of M. scabrinodis, M. rubra and M. ruginodis were pooled. Data coming from M. rugulosa nests were not included since larvae reared by this host species appeared to follow a slightly different growth path. Bonferroni correction was used for each post hoc comparison.

\section{Results}

Adoption of M. teleius larvae

In 65 Myrmica colonies (69\%) adoption was carried out successfully. There was a significant difference between the four Myrmica species in the proportion of successful adoptions of $M$. teleius larvae (Fisher exact test, $p=0.005$ ). M. teleius larvae were adopted by $83 \%$ (10 nests) of $M$. rugulosa, $76 \%$ (26 nests) of $M$. rubra, 58\% (21 nests) of $M$. scabrinodis and $25 \%$ (3 nests) of $M$. ruginodis colonies. Post hoc pairwise comparisons among species showed that adoption by colonies of $M$. ruginodis was significantly lower than by nests of M. rubra and M. rugulosa (Table 1).

Adoption was measured up to a maximum of $20 \mathrm{~h}$ $(1,200 \mathrm{~min})$ after the first contact and the median adoption
Table 1 Results of post hoc pairwise-comparison in the proportions of M. teleius larvae successfully adopted by different Myrmica species

\begin{tabular}{llll}
\hline & M. rubra & M. ruginodis & M. rugulosa \\
\hline M. scabrinodis & 0.056 & 0.037 & 0.08 \\
M. rubra & & $0.002^{*}$ & 0.2 \\
M. ruginodis & & & $0.005^{*}$ \\
\hline
\end{tabular}

$p$ values for Fisher exact test

* Significant results

Table 2 Results of post hoc pairwise-comparison in the adoption time of $M$. teleius larvae by different Myrmica species

\begin{tabular}{llll}
\hline & M. rubra & M. ruginodis & M. rugulosa \\
\hline M. scabrinodis & 0.04 & 0.39 & 0.06 \\
M. rubra & & $0.006^{*}$ & 0.15 \\
M. ruginodis & & & 0.018
\end{tabular}

$p$ values are given

* Significant results

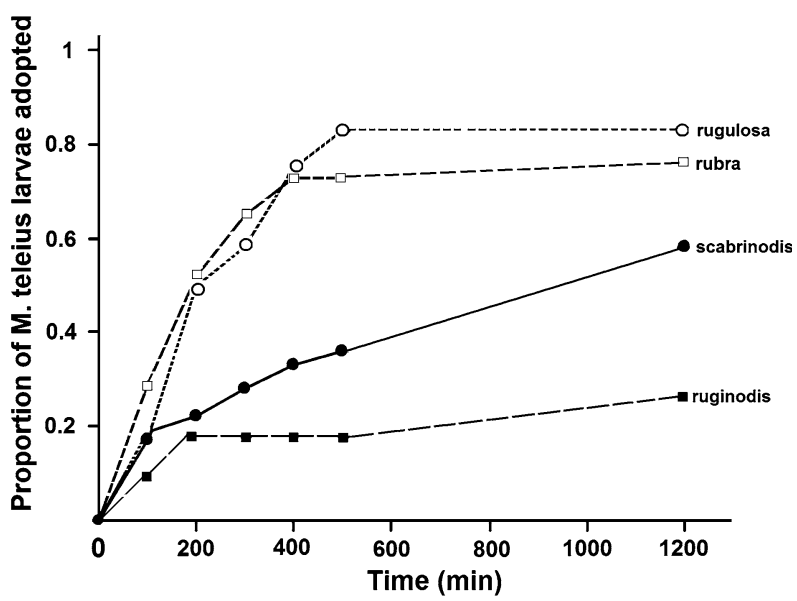

Fig. 1 Proportion of M. teleius larvae adopted by four host Myrmica species: M. scabrinodis (36 nests), M. rubra (34 nests), M. ruginodis (12 nests), M. rugulosa (12 nests)

times were: 166, 176, 840 and 1,191 min for M. rubra, M. rugulosa, $M$. scabrinodis and $M$. ruginodis, respectively. The adoption time was significantly different among the four Myrmica species (Log-Rank test, $\chi^{2}=12.63, d f=3$, $p=0.0055)$ and post hoc pairwise comparisons among species showed that colonies of $M$. rubra adopted M. teleius larvae significantly faster than colonies of $M$. ruginodis (Table 2; Fig. 1).

Survival and development of $M$. teleius larvae

Median survival time of M. teleius larvae in nests of host ant species was: 11.5 (0.5, 27 lower and upper quartiles) weeks 
for $M$. ruginodis, $10.0(0,29)$ for $M$. rubra, $7.0(3,13)$ for $M$. rugulosa and $3.0(0,29)$ for $M$. scabrinodis. There were no significant differences in the survival rate among $M$. teleius larvae from different Myrmica species (Log-Rank test, $\chi^{2}=3.43, d f=3, p=0.32$ ) although it should be noted that no larvae reared by $M$. rugulosa colonies survived beyond 20 weeks of observation (mid-November). The highest mortality rate was observed in the first week after adoption and towards the end of larval development (Fig. 2). At the end of the experiment only one caterpillar reared by a colony of $M$. rubra pupated successfully and later eclosed as an adult. There was no significant difference in M. teleius larvae surviving their first week after adoption between nests of the four Myrmica species $\left(\chi^{2}=3.48\right.$, $p=0.32$ ), although the lowest survival was observed in colonies of $M$. scabrinodis where $44 \%$ of the larvae died. In the other three species it ranged between 25 and $29 \%$.

In four of the 11 colonies without a queen, M. teleius larvae survived until the middle of the experiment (22 weeks) and this proportion was not different from those nests that contained a queen (in 31 nests with queen $M$. teleius larvae survived until 22 weeks, Fisher exact test, $p=0.25$ ).

The repeated measures ANOVA of body mass changes of caterpillars which survived until the 18th week (126 days) showed a significant effect of time $(F=38.87, d f=9,306$, $p<0.001)$ and of the interaction between time and the host ant species $(F=2.26, d f=27,306, p<0.001)$ but no significant effect of only the host ant species $(F=1.76$, $d f=3,34, p=0.17)$. The main observed difference concerns larvae reared within nests of M. rugulosa, where M. teleius larvae were the heaviest at the beginning of the larval development compared to larvae from other Myrmica ant nests, but then larval weight gain decreased and after 18 weeks and caterpillars from $M$. rugulosa nests were the smallest among all host ant species (Fig. 3).

The initial mean body mass $( \pm \mathrm{SD})$ of $M$. teleius larvae was $3.5 \pm 0.79 \mathrm{mg}$. After the first week of adoption this changed to $10.1 \pm 1.89 \mathrm{mg}$. In the seventh week after adoption, before winter, the mean body mass of larvae reached $13.1 \pm 1.83 \mathrm{mg}$ and then during the winter months a very slight decrease was observed. The second increase of $M$. teleius larval body mass was detected in the consecutive spring (Fig. 4). Interestingly, in the 38th week three of the six larvae that were still alive grew rapidly while the other three changed their body mass very slowly, leading to a high standard deviation in caterpillar mass (Fig. 4).

\section{Integration of $M$. teleius larvae}

In none of 17 Myrmica nests (nine nests of $M$. scabrinodis and eight of $M$. rubra) did worker ants carry M. teleius larvae to the new nests after destruction of the old one. In

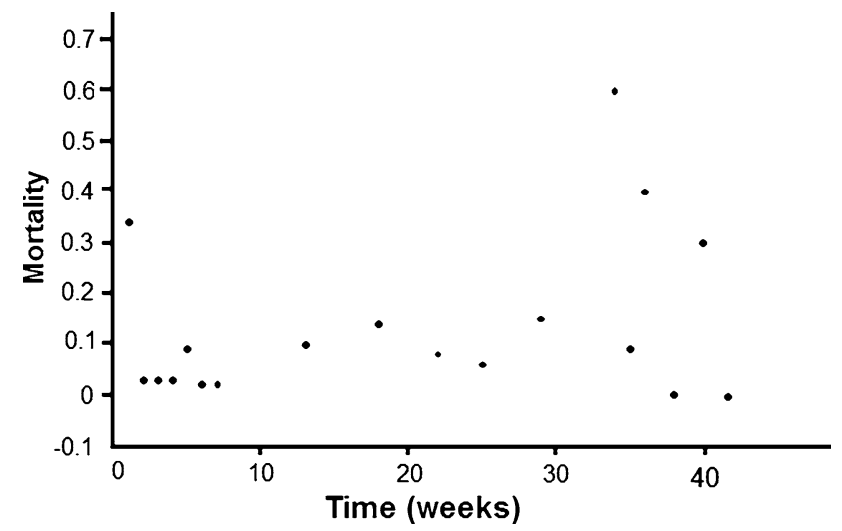

Fig. 2 Mortality rate of $M$. teleius larvae reared in the laboratory nest of four Myrmica species (M. scabrinodis, M. rubra, M. ruginodis and M. rugulosa)



Fig. 3 Body mass changes (mean $\pm \mathrm{SE}$ ) of M. teleius larvae reared in nests of four Myrmica host species during first 18 weeks after adoption



Fig. 4 Growth curve (mean $\pm \mathrm{SD}$ ) and survival curve of M. teleius larvae reared in the laboratory nests of three Myrmica species (the data for larvae from nests of $M$. scabrinodis, $M$. rubra and M. ruginodis were pooled together) 
contrast, Myrmica larvae were taken to the new nest chamber very quickly (mean time $\pm \mathrm{SE}, 2.9 \pm 0.71 \mathrm{~min}$ ). In only five nests contact of more than five seconds between worker ants and M. teleius larva was observed.

\section{Discussion}

Data from our laboratory experiment showed that the four investigated Myrmica host species differed in their adoption behaviour towards M. teleius larvae. M. rubra and M. rugulosa adopted $M$. teleius caterpillars more frequently than $M$. ruginodis. Moreover, adoption time was shorter in colonies of $M$. rubra than those of $M$. ruginodis (Fig. 1). It is known that all Myrmica species used in the experiment can build polygynous colonies (Czechowski et al., 2002) and $M$. rubra and $M$. rugulosa colonies are very often polygynous, containing a very high number of workers (several thousand individuals; Czechowski et al., 2002). This results in lower relatedness among worker nest mates (Elmes and Petal, 1990; Seppä and Walin, 1996). High genetic variance can be a beneficial for colonies of social insects (Hamilton, 1987; Sundström, 1995; Baer and Schmid-Hempel, 1999; Hughes and Boomsma, 2004), but on the other hand it can increase the likelihood of being infested by social parasites as the result of greater variance in nest-mate recognition cues. Gardner et al. (2007) showed that Microdon mutabilis (Linnaeus, 1758) (Diptera: Syrphidae), a social parasite of Formica lemani Bondroit, 1917 (Hymenoptera: Formicidae) ants, more often infests host colonies with lower genetic relatedness. A similar situation was found for colonies of M. rubra infested by M. alcon (Nash and Boomsma, 2008). Thus, the low relatedness inside $M$. rubra and $M$. rugulosa colonies may be an explanation for their higher adoption rate of $M$. teleius larvae.

There was no significant difference in the survival curves of $M$. teleius larvae reared by colonies of the four Myrmica host species. However, none of the larvae kept in nests of $M$. rugulosa survived for more than 20 weeks after adoption. We also did not find significant differences for initial integration, although $44 \%$ of larvae reared by $M$. scabrinodis colonies died during the first week of adoption, which is a rate almost twice as high as of the other Myrmica species. For cuckoo Maculinea butterflies (M. alcon and M. 'rebeli') it is known that initial integration with ant societies occurs during the first 24-48 h after adoption (Elmes et al., 2004). Additionally, it was shown that some Myrmica nests are more benign than others (Elmes et al., 2004) depending on the genotypic and social structure of the colony as well as environmental factors (Elmes et al., 2004). The initial integration of $M$. 'rebeli' larvae was faster by colonies of its main host ant species M. schencki (Emery, 1895) (Elmes et al., 2004). In our experiment, the slightly (but not sig- nificantly) lower initial survival of $M$. teleius larvae inside nests of $M$. scabrinodis is consistent with conclusions from the field that $M$. scabrinodis colonies may be less benign with M. teleius larvae in comparison to other Myrmica species (Witek et al., 2010). It was shown that M. scabrinodis was the most abundant Myrmica species in the metapopulation system in the Kraków region but the percentage of infested nests was similar or even lower than those of nests of $M$. rubra or $M$. ruginodis. Moreover, a decrease of infested nests of $M$. scabrinodis has been observed during the last 20 years (Thomas et al., 1989; Witek et al., 2010). This trend could be the consequence of the arms-race between the parasite and its host, which was also observed in other interactions between social parasites and their hosts (Lorenzi and Filippone, 2000; Foitzik et al., 2003; Nash et al., 2008). In this case, M. scabrinodis could evolve local resistance if the selection pressure by $M$. teleius was strong.

Three times higher mortality of $M$. arion larvae was shown inside ant nests with a queen in comparisons with those without a queen (Thomas and Wardlaw, 1990). However, in our study 11 Myrmica colonies lost the queen at the beginning of experiment, but there was no effect on the survival of $M$. teleius larvae. Moreover, five of six larvae that survived until late spring were reared inside colonies with the queen and only one came from a colony without a queen.

Comparisons of the initial integration of the predatory M. teleius with the cuckoo M. alcon and M. 'rebeli' (Schönrogge et al., 2004; Sielezniew and Stankiewicz, 2007) generally show a higher survival rate of the latter two cuckoo butterflies, although there are differences depending on the host ant species used. In our experiment, depending on the Myrmica ant species, 56-75\% of M. teleius larvae survived the first week of adoption, whereas survival of M. alcon larvae was more than $90 \%$ for primary host species and from 5 to $80 \%$ for non-host species (Sielezniew and Stankiewicz, 2007). Similar results were obtained for $M$. 'rebeli' where about $80-90 \%$ of the larvae survived in colonies of the primary host species (Schönrogge et al., 2004; Sielezniew and Stankiewicz, 2007) but 50\% (Schönrogge et al., 2004) or only $10 \%$ (Sielezniew and Stankiewicz, 2007) in non-host species. On the other hand, data obtained by Nash et al. (2011) shows that the mortality rate of M. alcon larvae was very high at the beginning of the larval development and contrary to other experiments on cuckoo butterflies it did not depend on host ant specificity. The authors demonstrated that the survival rate of $M$. alcon larvae was the highest in the nests of $M$. rubra even when butterflies originated from populations using $M$. ruginodis as their primary host.

It is known that cuticular hydrocarbons play an important role, both during the initial as well as the full integration 
phase of cuckoo Maculinea larvae with their host ant species (Akino et al., 1999; Elmes et al., 2002; Schönrogge et al., 2004; Nash et al., 2008). Schönrogge et al. (2004) showed that $M$. 'rebeli' larvae reared by colonies of its primary host species use chemical mimicry by an active production of hydrocarbons in addition to those found on pre-adoption larvae (and not necessarily shared with the host), whereas larvae kept in nests of non-host species seem to acquire chemical compounds from ants. Schönrogge et al. (2004) suggested that at least some of the compounds produced in the post-adoption stage by larvae of the cuckoofeeding $M$. 'rebeli' were related to the high status which these larvae achieve within host colonies. On the other hand, Nash et al. (2011) based on early stage survival of $M$. alcon larvae inside the nests of different host ants, concluded that butterfly caterpillars rely more on the passive acquiring the colony odour rather than on active production of mimetic compounds. Therefore, it is likely that different mechanisms are used during the initial adoption phase and during the later full integration phase. Also other significant factors such as acoustic cues can be involved (Barbero et al., 2009) and it may require a combination of such cues for workers to treat parasitic caterpillars preferentially over their own brood. Little is known about chemical profiles of pre- or post-adoption larvae of predatory Maculinea species, but the results from our experiment indicate a lower survival of M. teleius larvae during the initial integration in comparison with cuckoo Maculinea butterflies. It is important to note that the survival rate of predatory Maculinea species is generally lower in laboratory conditions than that of cuckoo ones (Wardlaw et al., 1998). The lack of statistical differences in the survival of $M$. teleius larvae reared by different Myrmica species suggests that $M$. teleius larvae may use at best 'chemical camouflage', which means acquisition of chemical signals from its hosts (Howard et al., 1990; Nash and Boomsma, 2008). Additionally, this hypothesis may be supported by the results of the integration experiment of $M$. teleius larvae with colonies of Myrmica host ants. In no case were $M$. teleius larvae taken by ant workers to new nests, which indicates a low level, or even absence, of integration with the host ant colony. Similar results were obtained for another predatory species, M. arion (Thomas et al., 1998). In the same paper the authors showed that, in the case of the cuckoo $M$. 'rebeli', the integration rate of larvae with colonies of the primary host was very high. It should be noted that 'initial integration' can take longer in the case of predatory than in cuckoo Maculinea butterflies, since the larvae need to obtain chemical compounds from their hosts. In our experiment we measured integration after $48 \mathrm{~h}$ from the moment of adoption similar to the experiment performed by Thomas et al. (1998) in order to obtain comparable results.

Despite the random assignment of $M$. teleius larvae to Myrmica colonies at the beginning of experiment, larvae put into nests of $M$. rugulosa turned out to be the heaviest (Fig. 3). On the other hand, higher initial weight did not give the larvae any advantage in survival. Furthermore, although the body mass of $M$. teleius larvae reared by colonies of M. rugulosa was the highest during the first week of adoption it then decreased and after 18 weeks it was the lowest among larvae adopted by other Myrmica species (Fig. 3). The growth pattern of $M$. teleius larvae inside colonies of M. scabrinodis, M. ruginodis and M. rubra was similar although larvae reared by nests of the latter two species were slightly heavier 18 weeks after adoption. The general larval growth pattern observed in cuckoo Maculinea comprises an increase of body mass at the beginning of the larval development during the first week of adoption and again shortly before pupation, as well as a slight decline of body mass during winter (Thomas and Wardlaw, 1992; Thomas et al., 1998; Elmes et al., 1991b; Sielezniew and Stankiewicz, 2007; Schönrogge et al., 2000; Sielezniew and Stankiewicz, 2007; Nash et al., 2011). In contrast to cuckoo Maculinea butterflies, $M$. teleius larvae seem to grow very slowly during the early larval development and the mean body mass reached at the beginning of the winter diapause was $14.6 \mathrm{mg}$ (Fig. 4). Data of the experiment of Nash et al. (2011) indicate that at the same time of larval development larvae of $M$. alcon reached a mean body mass from 25 to $55 \mathrm{mg}$ depending on the respective population and the host ant species. Similar results were obtained for $M$. 'rebeli' larvae which on average increased their body mass up to $60 \mathrm{mg}$ before winter (Thomas et al., 1998). In our study, the highest increase in M. teleius body mass was observed during the pre-pupation stage in spring (Fig. 4). It is also worth noting that both periods of rapid growth were associated with high mortality rates (Figs. 2, 4). In natural conditions larval survival is potentially further reduced by intraspecific competition. Interestingly, the separation of $M$. teleius larvae into fast and slow developers, which has also been observed in the field (Witek et al., 2006), occurred in May, in contrast to $M$. 'rebeli' and M. alcon in which fast and slow developers were already distinguishable in prewinter larvae (and this trend was particularly evident for larvae of M. 'rebeli'; Thomas et al., 1998; Schönrogge et al., 2000). The existence of both strategies (fast and slow developers) under similar laboratory conditions suggests that polymorphic growth has a strong genetic component (Gotthard, 2008).

It should be mentioned that the laboratory conditions such as food regime or temperature cycle, used in our experiments can influence results compared to those under natural conditions (see Tartally, 2004). On the other hand, the most important aim of the study was to compare adoption, survival rate and development of $M$. teleius larvae reared by different Myrmica host species with all ant colonies kept in the same laboratory conditions. This allows us 
to make among-species comparisons on the assumption that all Myrmica species are similarly adapted to laboratory conditions. Moreover, general conclusions from the laboratory experiments agree with those obtained in the field (Witek et al., 2010).

To summarize, our results indicate that particular Myrmica species found as hosts in the metapopulation in the Kraków region, differ in their ability to adopt and then rear M. teleius larvae, but it is not possible to observe a clear adaptation of this butterfly species to a particular host ant. Some Myrmica hosts, such as $M$. rugulosa, adopt larvae very quickly and readily but then the survival of the butterfly larvae is relatively low, whereas colonies of $M$. ruginodis had lower rates of adoption of $M$. teleius larvae, but later survival and increase in body mass for larvae was high. Additionally, it was not possible to show that $M$. scabrinodis, which was considered as the main host of $M$. teleius (Thomas et al., 1989), provided the best conditions for adoption and development of $M$. teleius larvae. Therefore, we have to conclude that some Myrmica species are better hosts during adoption and initial integration phases while others provide better conditions for the later development of M. teleius larvae. Similar conclusions can be derived from laboratory experiments by Als et al. (2001) and Nash et al. (2011) for larvae of M. alcon which used $M$. rubra and $M$. ruginodis as hosts. Results presented in this paper may explain why a multiple host use is observed in our $M$. teleius metapopulation and also in many other populations of this butterfly species.

Acknowledgments We would like to thank Anna Amirowicz, Marta Wantuch and Balbina Kudłek for their help with fieldwork and during laboratory experiments. We also wish to thank David Nash and András Tartally for helpful comments and corrections on this article. This study was supported by the EC within its FP5 RTD project MacMan (grant EVK2-CT-2001-00126 and the Biodiversa project CLIMIT; Settele and Kühn, 2009), a research grant of the Polish Ministry of Science and Higher Education (grant SPUB-3024) and also by research project NN304 075135 from the Polish Ministry of Science and Higher Education (D. Moroń).

Open Access This article is distributed under the terms of the Creative Commons Attribution Noncommercial License which permits any noncommercial use, distribution, and reproduction in any medium, provided the original author(s) and source are credited.

\section{References}

Akino T., Knapp J.J., Thomas J.A. and Elmes G.W. 1999. Chemical mimicry and host specificity in the butterfly Maculinea rebeli, a social parasite of Myrmica ant colonies. Proc. R. Soc. Lond. B. 266: $1419-1426$

Als T.D., Nash D.R. and Boomsma J.J. 2001. Adoption of parasitic Maculinea alcon caterpillars (Lepidoptera: Lycaenidae) by three Myrmica ant species. Anim. Behav. 62: 99-106
Als T.D., Vila R., Kandul N.P., Nash D.R., Yen S.H., Hsu Y.F., Mignault A.A., Boomsma J.J. and Pierce N.E. 2004. The evolution of alternative parasitic life histories in large blue butterflies. Nature 432: 386-390

Baer B. and Schmid-Hempel P. 1999. Experimental variation in polyandry affects parasite loads and fitness in a bumble-bee. Nature 397: 151-154

Barbero F., Thomas J.A., Bonelli S., Balletto E. and Schönrogge K. 2009. Queen ants make distinctive sounds that are mimicked by butterfly social parasite. Science 323: 782-785

Carr W.E. 1980. Fisher's exact test extended to more than two samples of equal size. Technometrics 22: 269-270

Czechowski W., Radczenko A. and Czechowska W. 2002. The Ants (Hymenoptera, Formicidae) of Poland. MIZ PAN. Warszawa, pp 141-143 and 166

Elmes G.W. and Petal J. 1990. Queen number as an adaptable trait: evidence from wild populations of two red ant species (genus Myrmica). J. Anim. Ecol. 59: 675-690

Elmes G.W., Thomas J.A. and Wardlaw J.C. 1991a. Larvae of Maculinea rebeli, a large blue butterfly, and their Myrmica host ants: wild adoption and behaviour in ant-nests. J. Zool. 223: 447-460

Elmes G.W., Wardlaw J.C. and Thomas J.A. 1991b. Larvae of Maculinea rebeli, a large blue butterfly, and their Myrmica host ants: patterns of caterpillar growth and survival. J. Zool. Lond. 224: 79-92

Elmes G.W., Thomas J.A., Hammarstedt O., Munguira M.L., Martin J. and van der Made J.G. 1994. Differences in host-ant specificity between Spanish, Dutch and Swedish populations of the endangered butterfly Maculinea alcon (Denis et Schiff.) (Lepidoptera). Memorab. Zool. 48: 55-68

Elmes G.W., Thomas J.A., Wardlaw J.C., Hochberg M.E., Clarke R.T. and Simcox D.J. 1998. The ecology of Myrmica ants in relation to the conservation of Maculinea butterflies. J. Insect. Conserv. 2: 67-78

Elmes G.W., Barr B., Thomas J.A. and Clark R.T. 1999. Extreme host specificity by Microdon mutabilis (Diptera: Syrphidae), a social parasite of ants. Proc. R. Soc. Lond. B. 266: 447-453

Elmes G.W., Akino T., Thomas J.A., Clarke R.T. and Knapp J.J. 2002. Interspecific differences in cuticular hydrocarbon profiles of Myrmica ants are sufficiently consistent to explain host specificity by Maculinea (large blue) butterflies. Oecologia 130: 525-535

Elmes G.W., Wardlaw J.C., Schönrogge K., Thomas J.A. and Clarke R.T. 2004. Food stress causes differential survival of socially parasitic caterpillars of Maculinea rebeli integrated in colonies of host and non-host Myrmica ant species. Entomol. Exp. Appl. 110: 53-63

Fiedler K. 1990. New information on the biology of Maculinea nausithous and Maculinea teleius (Lepidoptera: Lycaenidae). Nota Lepid. 4: 246-256

Figurny E. 1999. Myrmekofilne motyle Maculinea teleius i Maculinea nausithous, ich gospodarze i roślina żywicielska. [Myrmecophilous butterflies M. teleius and M. nausithous, their host ants and foodplants] Unpublished $\mathrm{PhD}$ thesis, Akadamia Rolnicza w Krakowie

Foitzik S., Fischer B. and Heinze J. 2003. Arms races between social parasites and their hosts: geographic patterns of manipulation and resistance. Behav. Ecol. 14: 80-88

Gardner M.G., Schönrogge K., Elmes G.W. and Thomas J.A. 2007. Increased genetic diversity as a defence against parasites is undermined by social parasites: Microdon mutabilis, hoverflies infesting Formica lemani ant colonies. Proc. R. Soc. Lond. B. 274: $103-110$

Gotthard K. 2008. Adaptive growth decisions in butterflies. BioScience 58: $222-230$ 
Hamilton W.D. 1987. Kinship, recognition, disease, and intelligence; constraints of social evolution. In: Animal Societies: Theory and Facts (Y. Ito, J.L. Brown and J. Kikkawa, Eds). Japanese Scientific Society Press, Tokyo. pp 81-102

Howard R.W., Akre R.D. and Garnett W.B. 1990. Chemical mimicry in an obligate predator of carpenter ants (Hymenoptera, Formicidae). Ann. Entomol. Soc. Am. 83: 607-616

Hölldobler B. and Wilson E.O. 1990. The Ants. Springer Verlag, Berlin, $732 \mathrm{pp}$

Hughes W.O.H. and Boomsma J.J. 2004. Genetic diversity and disease resistance in leaf-cutting ant societies. Evolution 58: 1251-1260

Lorenzi M.C. and Filippone F. 2000. Opportunistic discrimination of alien eggs by social wasps (Polistes biglumis, Hymenoptera: Vespidae): a defense against social parasitism? Behav. Ecol. Sociobiol. 48: 402-406

Nash D.R. and Boomsma J.J. 2008. Communication between hosts and social parasites. In: Sociobiology of Communication - an Interdisciplinary Approach (P. d'Ettorre and D.P. Hughes, Eds), Oxford University Press, Oxford, pp 55-79

Nash D.R., Als T.D., Maile R., Jones G.R. and Boomsma J.J. 2008. A mosaic of chemical coevolution in a large blue butterfly. Science 319: $88-90$

Nash D.R., Als T. D. and Boomsma J.J. 2011. Survival and growth of parasitic Maculinea alcon caterpillars (Lepidoptera, Lycaenidae) in nests of three Myrmica ant species. Insect. Soc. 58 (in press)

Nowicki P., Pępkowska A., Kudłek J., Skórka P., Witek M., Settele J. and Woyciechowski M. 2007. From metapopulation theory to conservation recommendations: Lessons for special occurrence and abundance patterns of Maculinea butterflies. Biol. Cons. 140: 119-129

Patricelli D., Witek M., Barbero F., Casacci L.P., Bonelli S. and Balletto E. 2010. Evidence of high larval host ant specificity in the first post adoption phase for the myrmecophilous butterfly Phengaris (Maculinea) nausithous (Lepidoptera: Lycaenidae). Sociobiology 55: 861-870

Schönrogge K., Wardlaw J.C., Thomas J.A. and Elmes G.W. 2000. Polymorphic growth rates in myrmecophilous insects. Proc. R. Soc. Lond. B 267: 771-777

Schönrogge K., Wardlaw J.C., Peters A.J., Everett S., Thomas J.A. and Elmes G.W. 2004. Changes in chemical signature and host specificity from larval retrieval to full social integration in the myrmecophilous butterfly Maculinea rebeli. J. Chem. Ecol. 30: 91-107

Seppä P. and Walin L. 1996. Sociogenetic organization of the red ant Myrmica rubra. Behav. Ecol. Sociobiol. 38: 207-217

Settele J. and Kühn E. 2009. Insect conservation. Science 325: 41-42

Sielezniew M. and Stankiewicz A. 2007. Differences in the development of the closely related myrmecophilous butterflies Maculinea alcon and M. rebeli (Lepidoptera: Lycaenidae). Eur. J. Entomol. 104: $433-444$

Stankiewicz A. and Sielezniew M. 2002. Host specificity of Maculinea teleius Bgstr. and M. nausithous Bgstr. (Lepidoptera: Lycaenidae). The new insight. Ann. Zool. 52: 403-408

Sundström L. 1995. Sex allocation and colony maintenance in monogyne and polygyne colonies of Formica truncorum (Hymenoptera: Formicidae) - the impact of kinship and mating structure. Am. Nat. 146: 182-201

Śliwińska E.B., Nowicki P., Nash D.R., Witek M., Settele J. and Woyciechowski M. 2006. Morphology of caterpillars and pupae of European Maculinea species (Lepidoptera: Lycaenidae) with identification table. Entomol. Fenn. 17: 351-358

Tartally A. and Csősz S. 2004. Adatok a magyarországi Maculinea fajok (Lepidoptera: Lycaenidae) hangyagazdáiról. [Data on the ant hosts of the Maculinea butterflies (Lepidoptera: Lycaenidae) of Hungary]. Term.véd. Közlem. 11: 309-317

Tartally A. 2004. Accelerated development of Maculinea rebeli larvae under artificial conditions (Lycaenidae). Nota Lepid. 27: 303-308

Tartally A. and Varga Z. 2008. Host ant use of Maculinea teleius in the Carpathian Basin (Lepidoptera: Lycaenidae). Acta Zool. Acad. Sci. H. 54: 257-268

Thomas J.A. 2002. Larval niche selection and evening exposure enhance adoption of a predacious social parasite, Maculinea arion (large blue butterfly) by Myrmica ants. Oecologia 132: 531-537

Thomas J.A. and Elmes G.W. 1998. Higher productivity at the cost of increased host-specificity when Maculinea butterfly larvae exploit ant colonies through trophallaxis rather than by predation. Ecol. Entomol. 23: 457-464

Thomas J.A. and Settele J. 2004. Butterfly mimics of ants. Nature 432: 283-284

Thomas J.A. and Wardlaw J.C. 1990. The effect of queen ants on the survival of Maculinea arion in Myrmica ant nests. Oecologia 85: 87-91

Thomas J.A and Wardlaw J.C. 1992. The capacity of a Myrmica ant nest to support a predacious species of Maculinea rebeli inhabitants in ant nests. Oecologia 91: 101-109

Thomas J.A., Elmes G.W., Wardlaw J.C. and Woyciechowski M. 1989. Host specificity among Maculinea butterflies in Myrmica ant nests. Oecologia 79: 452-457

Thomas J.A., Elmes G.W. and Wardlaw J.C. 1998. Polymorphic growth in larvae of the butterfly Maculinea rebeli, a social parasite of Myrmica ant colonies. Proc. R. Soc. Lond. B. 265: 1895-1901

Thomas J.A., Schönrogge K. and Elmes G.W. 2005. Specialization and host associations of social parasites of ants. In: Insect Evolutionary Ecology. CABI Publishing, Wallingford, U.K. pp 475-514

Wardlaw J.C., Elmes G.W. and Thomas J.A. 1998. Techniques for studing Maculinea butterflies: I. Rearing Maculinea caterpillars with Myrmica ants in the laboratory. J. Insect Conserv. 2: 59-66

Wardlaw J.C., Thomas J.A. and Elmes G.W. 2000. Do Maculinea rebeli caterpillars provide vestigial mutualistic benefits to ants when living as social parasites inside Myrmica ant nests? Entomol. Exp. Appl. 95: 97-103

Witek M., Sliwinska E., Skorka, P., Nowicki P., Settele J. and Woyciechowski M. 2006. Polymorphic growth in larvae of Maculinea butterflies, as an example of biennialism in myrmecophilous insects. Oecologia 148: 729-733

Witek M., Śliwińska E.B., Skórka P., Nowicki P., Wantuch M., Vrabec V., Settele J. and Woyciechowski M. 2008. Host ant specificity of Large Blue butterflies Maculinea (Maculinea) (Lepidoptera: Lycaenidae) inhabiting humid grassland in East-central Europe. Eur. J. Entomol. 105: 871-877

Witek M., Nowicki P., Śliwińska E.B., Skórka P., Settele J., Schönrogge K. and Woyciechowski M. 2010. Local host ant specificity of Phengaris (Maculinea) teleius butterfly, an obligatory social parasite of Myrmica ants. Ecol. Entomol. 35: 557-564

Woyciechowski M., Slowik J. and Muehlenberg M. 2006. Hosts of the butterfly Maculinea teleius among Myrmica ants in northern Mongolia. Sociobiology 48: 493-502 